\title{
EDUKASI KESEHATAN TENTANG POLA MAKAN DAN LATIHAN FISIK UNTUK PENGELOLAAN REMAJA UNDERWEIGHT
}

\author{
Zahtamal ${ }^{1)}$, Sri Melati Munir ${ }^{2)}$ \\ ${ }^{1}$ Prodi Pendidikan Dokter, Fakultas Kedokteran, Universitas Riau \\ ${ }^{2}$ Fakultas Kedokteran, Universitas Riau \\ afisifeizah@gmail.com,melpulmo@yahoo.com
}

\begin{abstract}
Abstrak
Pada saat ini banyak remaja yang mengalami kondisi gizi kurang (underweight). Hal ini disebabkan oleh karena asupan makanan dengan gizi seimbang masih belum optimal terpenuhi. Tujuan dari kegiatan ini adalah untuk meningkatkan perilaku remaja dalam hal mencegah dan mengatasi underweight dengan fokus pada pola asupan makanan dan latihan fisik. Kegiatan pengabdian kepada masyarakat ini dilakukan dengan metode pengukuran status gizi dan penyuluhan yang diberikan melalui ceramah tanya jawab dengan menggunakan media presentasi power point yang dikombinasi dengan poster yang materinya berkaitan dengan topik/materi, diskusi, demonstrasi, dan simulasi. Jumlah sasaran pada kegiatan ini adalah sebanyak 33 remaja. Instrumen pada kegiatan ini adalah timbangan berat badan dan microtoice untuk mendapatkan indeks masa tubuh (IMT) dan kuesioner. Hasil dari kegiatan ini adalah telah diketahuinya bahwa terdapat $54,5 \%$ dari peserta mengalami underweight. Setelah diberikan edukasi terjadi peningkatan pengetahuan dan kesadaran remaja tentang kondisi underweight.
\end{abstract}

Keywords: edukasi kesehatan, kesadaran, pengetahuan, gizi kurang

\begin{abstract}
At this time many adolescents with underweight conditions. This is because food intake with balanced nutrition is still not optimally fulfilled. The purpose of this activity is to improve adolescent behavior in terms of preventing and overcoming underweight with a focus on patterns of food intake and physical exercise. The community service activities have been carried out at the "Pekanbaru Amanah Orphanage" from July to October 2018 with the method of measuring nutritional status and counseling given through question and answer lectures using power point presentation media combined with posters. The counseling material that has been given is related to the purpose of service, discussion, demonstration, and simulation. The number of targets in this activity were 33 teenagers. The instruments that have been used in this activity are weight and microtoice scales to obtain body mass index (BMI) and questionnaires. The result of this activity is that there are $54.5 \%$ of participants experiencing underweight. After being educated there was an increase in the knowledge and awareness of adolescents about underweight conditions.
\end{abstract}

Keywords: awareness, health education, knowledge, underweight

\section{PENDAHULUAN}

Remaja menurut World Health Organization (WHO) berusia antara 10-19 tahun (Pratiwi, 2017). Remaja bagian dari sumberdaya manusia dan merupakan penerus bangsa. 
Secara fisik, dan intelektual, pertumbuhan dan perkembangan pada usia remaja terjadi sangat pesat. Beberapa faktor yang mempengaruhi hal ini, diantaranya adalah pola asupan makanan, latihan fisik dan kondisi kesehatan. Selain itu perubahan psikisosial remajapun mengalami perubahan, yaitu dari masa anak-anak ke menjelang dewasa. Sehingga masa remaja sering disebut masa peralihan, yakni dari masa anak yang mengalami perkembangan semua aspek atau fungsi untuk memasuki masa dewasa.

Perubahan psikososial remaja terbagi dalam tiga tahap yaitu remaja awal, pertengahan dan akhir. Pencarian identitas diri pada remaja sangat berpengaruh terhadap kehidupannya mendatang dan mulai mengalami kemandirian yang tidak terkontrol, karena tidak menginginkan orang tua terlibat lagi dalam kehidupannya. Hal ini dapat mempengaruhi remaja dalam berperilaku, termasuk dalam memenuhi nutrisi yang cukup, misalnya mereka mulai memperhatikan penampilannya dengan diet tertentu yang terkadang tidak efektif/salah (Poltekkes Depkes Jakarta I, 2010).

Kebutuhan gizi yang diperoleh dari makanan merupakan hal yang sangat penting. Berdasarkan Riset Kesehatan Dasar (Riskesdas) tahun 2013 status gizi remaja di Indonesia untuk kelompok umur 13-15 tahun menunjukkan prevalensi kurus pada remaja umur adalah $11,1 \%$ terdiri dari 3,3\% sangat kurus dan 7,8\% kurus. Sedangkan prevalensi kurus pada remaja umur 16-18 tahun sebesar 9,4\% terdiri dari 1,9\% sangat kurus dan 7,5\% kurus. Remaja di provinsi Riau umur 13-15 tahun didapatkan prevalensi sangat kurus 3,4\% dan kurus 8,1\%, remaja umur 16-18 tahun dengan prevalensi sangat kurus 2,0\% dan kurus 5,9\% (Departemen Kesehatan Republik Indonesia, 2010).

Keadaan kurang gizi akan memberikan dampak buruk terhadap kondisi kesehatan fisik, mental, intelektual dan sosial anak remaja. Penelitian Desi menyatakan bahwa akibat dari kekurangan gizi dapat menyebabkan kognitif dan kemampuan belajar terganggu, serta menurunkan konsentrasi. Penelitian Florence (2017) menyatakan bahwa terdapat hubungan yang bermakna antara pengetahuan gizi dengan status gizi. Selanjutnya, dijelaskan bahwa kesalahan dalam memilih makanan dan kurang cukupnya pengetahuan tentang gizi akan mengakibatkan timbulnya masalah gizi yang akhirnya mempengaruhi status gizi. Untuk itu, upaya edukasi kesehatan diperlukan dalam rangka meningkatkan perilaku remaja dalam mengatasi masalah status gizinya. Selain faktor pengetahuan, pola asuh pemberian makanan dan peran pendampingan dari orang tua/orang tua asuh juga akan berpengaruh terhadap status gizi remaja. Salah satu kelompok remaja yang berisiko mengalami gangguan gizi, termasuh underweight adalah remaja penghuni panti asuhan.

Salah satu panti asuhan yang juga banyak dihuni oleh para remaja baik laki-laki maupun perempuan adalah panti Asuhan Amanah Pekanbaru. Panti sosial asuhan anak ini dikelola oleh yayasan kesatuan Wanita Islam (YKWI) Pekanbaru. Jumlah anak remaja pria yang diasuh di panti ini ada sekitar 40 orang. Berdasarkan wawancara dengan pengelola panti, sumber makanan untuk kebutuhan anak panti berasal dari donatur dan amal usaha yang dijalankan oleh pengelola panti. Selanjutnya, dari gambaran fisik remaja penghuni panti, banyak remaja yang mengalami underweight, khusunya pada remaja pria. Salain itu, edukasi kesehatan termasuk pengelolaan status gizi pada remaja penghuni panti selama ini masih dirasa kurang.

Kegiatan pengabdian kepada masyarakat ini dilakukan dengan tujuan diperolehnya data kondisi gizi kurang (underweight) pada remaja penghuni Panti Asuhan Amanah Pekanbaru, serta meningkatkan pengetahuan dan kesadaran, remaja tentang kondisi gizi kurang (underweight). 


\section{METODE PELAKSANAAN}

Metode pelasksanaan kegiatan pengabdian kepada masyarakat adalah melakukan penilaian status gizi untuk mendapatkan gambaran gizi kurang (underweight) di lokasi pengabdian. Selanjutnya, melakukan penyuluhan dengan metode ceramah dan tanya jawab disertai dengan pemberian media ajar dan pemutaran video untuk medapatkan peningkatan pengetahuan, dan kesadaran remaja tentang kondisi underweight. Kegiatan pengabdian kepada masyarakat ini telah dilakukan pada bulan Juni sampai dengan Oktober 2018. Tempat kegiatan adalah di Panti Asuhan Amanah Pekanbaru yang berlokasi di jalan Harapan Raya gang Nangka 6, Tangkerang Utara, Bukit Raya, Pekanbaru. Untuk mendapatkan data hasil pengabdian, digunakan pita meteran, timbangan (BB) untuk data status gizi remaja. Instrumen berikutnya adalah kuesioner untuk data perilaku remaja.

\section{HASIL DAN PEMBAHASAN}

Masyarakat sasaran dalam kegiatan pengabdian kepada masyarakat ini adalah anak usia remaja yang ada di Panti Asuhan Amanah Pekanbaru. Anak remaja penghuni Panti Asuhan ini sebagian besar berstatus pelajar baik setingkat SMP maupun SMA. Secara umum, untuk kebutuhan makanan sehari-hari, anak remaja penghuni panti mendapatkan sumber makanan dari para donatur baik yang tetap maupun insidentil dari masyarakat sekitar Kota Pekanbaru. Makanan diolah oleh juru masak pengelola panti. Dengan keterbatasan yang dimiliki dan jumlah penghuni panti yang banyak, terkadang kebutuhan gizi makanan anak dirasa belum optimal. Terkait dengan fasilitas latihan fisik, di panti ini sudah tersedia lapangan yang dapat dimanfaatkan untuk sarana olahraga, seperti sepakbola, arena bermain sepeda, badminton, voliball, dan lain lain.

Upaya pemberdayaan ini difokuskan pada penguatan/peningkatan perilaku remaja khusunya dalam mengenal lebih mendalam kondisi kurang gizi dan bagaimana mencegah dan mengelolanya. Upaya ini dilakukan dikarenakan usia sasaran yang masih muda, potensi mengingat pesan/ informasi masih cukup baik, sudah dapat mengambil dan membuat keputusan untuk mengurus diri sendiri atau berperilaku sehat. Selain itu, adanya ketersediaan sarana latihan fisik, sangat memungkinkan sasaran bisa menerapkan ilmu yang didapat, khususnya dalam perilaku latihan fisik untuk mencegah dan mengelola kondisi underweight.

Pelaksanaan kegiatan pengabdian diawali dengan wawancara dengan pihak pengelola Panti Asuhan Amanah Pekanbaru. Pada kegiatan ini diperoleh gambaran umum kondisi anak remaja penghuni panti; kondisi status gizi mereka, asupan makanan yang diperoleh dan pola aktivitas fisiknya. Selain itu, didapatkan juga informasi bahwa edukasi kesehatan tentang pencegahan dan pengelolaan gizi kurang belum pernah dilakukan.

Telah dilakukan pengukuran IMT untuk mendapatkan gambaran status gizi sasaran. Berdasarkan kriteria IMT untuk kawasan Asia pacific, diketahui bahwa dari 33 orang peserta terdapat 18 orang remaja (54,5\%) mengalami kurang gizi (underweight). Angka ini di atas temuan Riskesdas 2013, yang menemukan persentase remaja yang kurus dan sangat kurus pada kelompok umur 13-15 sebesar 11,1\% dan pada remaja umur 16-18 tahun sebesar 9,4\%. Begitu juga di Provinsi Riau yang hanya 11,5\%. 
Tabel.1 Kategori status gizi peserta penyuluhan

\begin{tabular}{lcc}
\hline $\begin{array}{c}\text { Kategori } \\
\text { status gizi }\end{array}$ & Jumlah & $\begin{array}{c}\text { Persentase } \\
(\boldsymbol{\%})\end{array}$ \\
\hline Underweight & 18 & 54.5 \\
\hline Normoweight & 12 & 36.4 \\
\hline Overweight & 3 & 9.1 \\
\hline Total & $\mathbf{3 3}$ & $\mathbf{1 0 0}$ \\
\hline
\end{tabular}

Pengukuran status gizi dapat dilihat pada gambar 1 berikut:

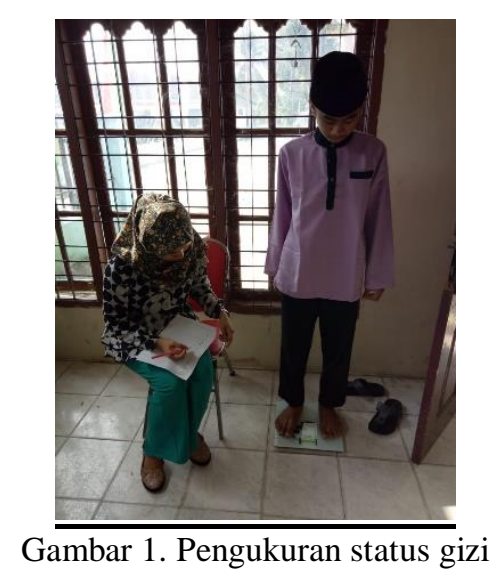

Rangkaian kegiatan pengabdian kepada masyarakat berikutnya adalah edukasi kesehatan. Tujuan dari kegiatan ini adalah meningkatnya perilaku (pengetahuan dan kesadaran) remaja tentang kondisi kurang gizi (underweight). Kegiatan ini diikuti oleh 33 orang remaja. Sebagai narasumber pada kegiatan ini adalah dosen tim pengabdian kepada masyarakat Fakultas Kedokteran Universitas Riau.

Edukasi/penyuluhan dibuka dengan penyampaian kata sambutan dari perwakilan pengelola Panti Asuhan Amanah Pekanbaru sekaligus membuka acara. Ada tiga materi utama yang disampaikan saat edukasi/penyuluhan dan kemudian dilakukan pemutaran video tentang motivasi asupan makanan dan latihan fisik untuk mencegah dan mengelola kondisi kurang gizi.

Sebelum diberikan materi edukasi, peserta penyuluhan diberi kuesioner. Pembagian kuesioner juga dilakukan setelah edukasi. Pengukuran pengetahuan dan kesadaran peserta dengan kuesioner dapat dilihat pada gambar 2 berikut:

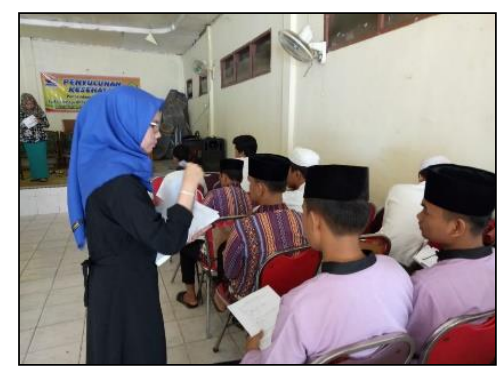

Gambar 2. Pengisian kuesioner oleh peserta penyuluhan 
Materi edukasi pertama disampaikan oleh dr. Sri Melati Munir, Sp.P (K). Materi yang disampaikan adalah Konsep dasar gizi kurang, mencakup: Pengertian gizi kurang, kriteria gizi kurang, penyebab dan faktor risiko gizi kurang, dampak gizi kurang, tatalaksana gizi kurang/ program pengelolaan gizi kurang pada remaja. Pembicara kedua oleh Yanti Ernalia, Dietisien, M.PH, Materi yang diampaikan yaitu tentang pengaturan asupan makanan bagi remaja yang underweight mencakup; Pentingnya Gizi Remaja, Kebutuhan Gizi Remaja, Pengaturan Gizi Remaja Kurus (Kekurangan Berat Badan) dan Pengaturan menu Remaja Kurus. Selanjutnya, pembicara ketiga adalah Dr. Zahtamal, SKM, M.Kes. Penyampaian materi tentang latihan fisik dalam mengelola underweight pada remaja, yang mencakup: jenis latihan fisik bagi penderita gizi kurang, program latihan fisik untuk menaikkan berat badan, dan prinsip dasar penambahan berat badan dari otot.
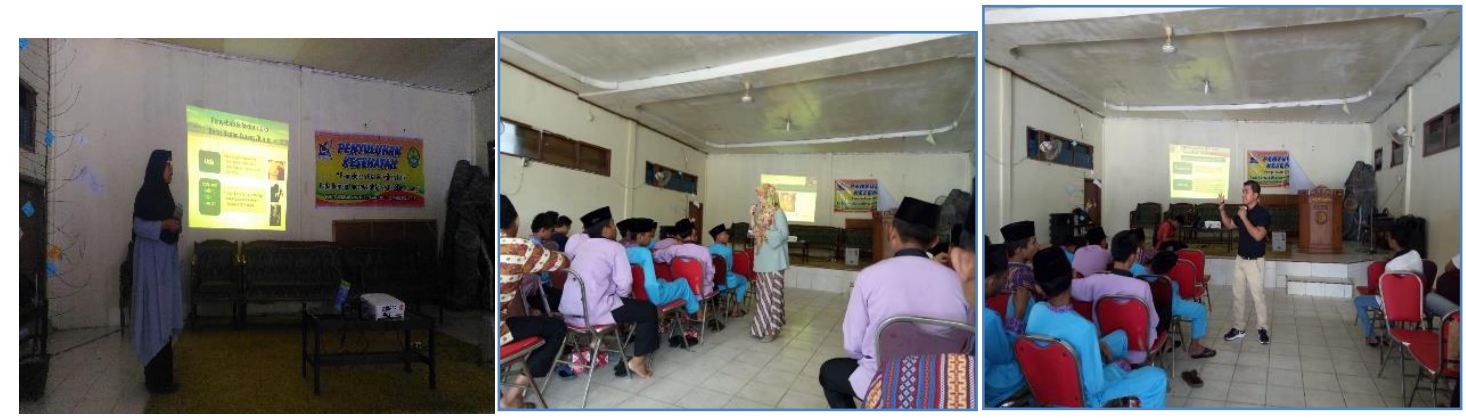

Gambar 3. Proses penyampaian materi eduaksi kesehatan

Secara umum kegiatan ini telah berjalan dengan baik dan lancar, sesuai dengan agenda serta diikuti dengan antusias sasaran. Hal ini terlihat dari kehadiran sasaran dari awal acara sampai berakhirnya kegiatan dan keaktifan sasaran dalam edukasi, banyak umpan balik/feed back dalam bentuk tanya jawab. Kegiatan ini juga telah memberikan dampak pada peningkatan pengetahuan dan kesadaran remaja tentang kondisi gizi kurang (underweight).

Secara umum kegiatan ini telah berjalan dengan baik dan lancar, sesuai dengan agenda serta diikuti dengan antusias sasaran. Hal ini terlihat dari kehadiran sasaran dari awal acara sampai berakhirnya kegiatan dan keaktifan sasaran dalam edukasi, banyak umpan balik/feed back dalam bentuk tanya jawab. Kegiatan ini juga telah memberikan dampak pada peningkatan pengetahuan dan kesadaran remaja tentang kondisi gizi kurang (underweight).

Berdasarkan pengolahan data, untuk melihat efektivitas edukasi yang dilakukan didapatkan hasil sebagai berikut:

Tabel 2. Analisis perbedaan pengetahuan dan kesadaran terhadap aktivitas fisik dan pola makan sebelum dan setelah edukasi

\begin{tabular}{llll}
\hline $\begin{array}{l}\text { Variabel } \\
\text { perilaku }\end{array}$ & \multicolumn{1}{c}{$\begin{array}{l}\text { Rerata } \\
\text { Pratest }\end{array}$} & $\begin{array}{c}\text { Rerata } \\
\text { Postest }\end{array}$ & $\begin{array}{c}\text { P } \\
\text { value }\end{array}$ \\
\hline $\begin{array}{l}\text { Kesadaran } \\
\text { aktivitas }\end{array}$ & $\begin{array}{l}66,67 \pm \\
\text { fisik }\end{array}$ & $\begin{array}{l}70(40-26 \\
100)\end{array}$ & $0,247^{\mathrm{a}}$ \\
fisikan & $60(10$ & $64 \quad \pm$ & $1.0^{\mathrm{a}}$ \\
\hline $\begin{array}{l}\text { Kesadaran } \\
\text { pola makan }\end{array}$ & $-80)$ & 20,3 & \\
\hline
\end{tabular}




\begin{tabular}{llll}
\hline $\begin{array}{l}\text { Pengetahuan } \\
\text { aktivitas }\end{array}$ & $38,79 \pm$ & $53,94 \pm 0,000^{\mathrm{b}}$ \\
fisik & 16,15 & 15,99 & \\
\hline Pengetahuan & $56,97 \pm$ & $67,27 \pm 0,003^{\mathrm{b}}$ \\
pola makan & 15,31 & 18,08 & \\
\hline $\begin{array}{l}\text { Ket: } \\
\text { a di uji dengan Wilcoxon test } \\
\text { b diuji dengan paired sample t test }\end{array}$
\end{tabular}

Berdasarkan Tabel 2 di atas diketahui bahwa edukasi yang telah dilakukan dapat secara bermakna meningkatkan pengetahuan remaja baik mengenai pola aktivitas fisik maupun pola makan. Akan tetapi, walaupun terjadi peningkatan skor baik kesadaran terhadap aktivitas fisik dan pola makan sebelum dan setelah edukasi namun perbedaan tersebut belum signifikan. Artinya edukasi kesehatan yang dilakukan efektif untuk meningkatkan pengetahuan remaja/peserta edukasi, akan tetapi belum optimal dalam meningkatkan kesadaran. Hal ini sejalan dengan teori perilaku, bahwa edukasi kesehatan dapat seketika meningkatkan pengetahuan seseorang (ranah kognitif), akan tetapi efek seketika belum tentu ditunjukkan oleh variable perilaku lainnya, seperti kesadaran. Hasil kegiatan ini sejalan dengan pendapat de Vries et al. (2008), bahwa tujuan promosi kesehatan adalah untuk meningkatkan pengetahuan seseorang.

\section{SIMPULAN}

Berdasarkan hasil kegiatan dapat disimpulkan bahwa kondisi gizi kurang (underweight) pada remaja penghuni Panti Asuhan Amanah Pekanbaru, yakni 18 orang peserta/sasaran pengabdian dari 33 peserta (54,5\%). Setalah dilakukan edukasi didapatkan adanya peningkatan pengetahuan, kesadaran, remaja tentang kondisi gizi kurang (underweight). Beberapa hal yang disarankan antara lain; 1) Untuk

Puskesmas Harapan Raya dan Puskesmas Sapta Taruna Pekanbaru, supaya dapat menindak lanjuti temuan masih banyaknya remaja yang mengalami gizi kurang, dengan melaksanakan upaya pengelolaan secara lintas program dan lintas sektor, Untuk pengelola panti, dapat lebih meningkatkan dan memberikan perhatian lebih terhadap asupan makanan penghuni panti dengan menyediakan makanan dengan menu seimbang serta memberikan peluang baik waktu maupun sarana bagi anak/penghuni panti untuk melakukan latihan fisik yang sehat

\section{DAFTAR PUSTAKA}

Departemen Sosial Republik Indonesia. (2004). Acuan umum pelayanan sosial anak di panti sosial asuhan anak. Jakarta: Departemen sosial.

Departemen Kesehatan Republik Indonesia. (2013). Riset kesehatan dasar provinsi Riau. Jakarta: Depkes RI.

de Vries, H., Kremers, S.P.J., Smeets, T., Brug, J., Eijmael, K. (2008). The effectiveness of tailored feedback and action plans in an intervention addressing multiple health behaviors. Am J Health Promot, 22: 417-425 
Florence, A.G. (2017). Hubungan pengetahuan gizi dan pola konsumsi dengan status gizi pada mahasiswa TBP sekolah bisnis dan manajemen Institut Teknologi Bandung Skripsi. Bandung: Program Studi Teknologi Pangan Fakultas Teknik Universitas Pasundan.

Kementrian Kesehatan RI. (2011 $)$. Standar antropometri penilaian status gizi anak. Jakarta: Depkes.

Kementrian Kesehatan RI. (2011 $)$. Pedoman gizi seimbang. Jakarta: Kemenkes. Diakses tanggal 23 Februari 2018. Tersedia di http://gizi.depkes.go.id/download/Pedoman\% 20Gizi/PGS\%20Ok.pdf.

Poltekkes Depkes Jakarta I. (2010). Kesehatan Remaja: Problem dan Solusi. Jakarta: Salemba Medika.

Pratiwi R.P., (2017). Kesehatan remaja di Indonesia. [Diakses 1 November 2017]. Tersedia di: http://www.idai.or.id/artikel/ seputar-kesehatan-anak/kesehatanremaja-di-indonesia 